SERĐO KOS, Ph.D. ${ }^{1}$

E-mail: skos@pfri.hr

MARIO BAKOTA, mag.ing.naut. ${ }^{2}$

E-mail: mbakota@pfst.hr

(Corresponding author)

DAVID BRČIĆ, Ph.D. ${ }^{1}$

E-mail: brcic@pfri.hr

1 University of Rijeka, Faculty of Maritime Studies

Studentska 2, 51000 Rijeka, Croatia

2 University of Split, Faculty of Maritime Studies

Ruđera Boškovića 37, 21000 Split, Croatia
Traffic Planning

Review

Submitted: 18 July 2017

Accepted: 12 Apr. 2018

\title{
ANALYSIS OF THE IMPACT OF TRANSPORT CORRIDOR Vc ON THE PORT OF PLOČE
}

\begin{abstract}
The importance of the Port of Ploče lies in serving the majority of the Bosnian market. However, the Pan-European Corridor Vc provides access to a much wider market in Central and South-Eastern Europe. The purpose of this paper is to express views on the future development of the Corridor and its consequential impact on the Port. This was conducted by means of analysis, comparison, and synthesis of cargo flow data and the dynamics data of the Corridor Vc construction. It covers the relations between Bosnia and Herzegovina $(\mathrm{BiH})$ and the Republic of Croatia, and the assessment of importance of the Corridor in those countries. Statistical indicators show the importance of the Corridor completion for the successful execution of port development plans. The analysis of the Corridor status points to the current prevailing circumstances in $\mathrm{BiH}$ that make its realization ultimately uncertain, especially its railway component. The findings show that the most significant obstacles for a successful realization of Port of Ploče development plans are not only within the $\mathrm{BiH}$ internal geo-political relationships but in the disputes between $\mathrm{BiH}$ and the Republic of Croatia $(\mathrm{RH})$ as well. Consequently, it has been shown that the Port of Ploče is not able to define and carry out the necessary measures toward $\mathrm{BiH}$ on its own but necessarily with the participation of the RH Government. The analysis offers observations and recommendations for improving relations with $\mathrm{BiH}$, which would significantly advance the completion of the Corridor in $\mathrm{BiH}$. In this way, it would allow for a full establishment of the Port of Ploče on target markets.
\end{abstract}

\section{KEY WORDS}

the Port of Ploče; cargo flows; Corridor Vc construction; BiH territorial cohesion;

\section{INTRODUCTION}

The advantages of Republic of Croatia's geostrategic position have been recognized in designation of international transport corridors. All EU Member States participate in the Trans-European Network for Transport Programme (TEN-T) [1] that involves all modes of transport - road, rail, waterborne (maritime and inland waterways), and air transport (Malta and Cyprus do not participate in the rail component of TEN-T). Intelligent and logistic transport systems are covered as well [2].

The TEN-T network is a part of the greater system of the Trans-European Network (TEN) that involves trans-European telecommunications networks (eTEN) and the proposed Trans-European Networks for Energy (TEN-E) [3].

Two basic TEN-T corridors pass through Croatia: the Mediterranean corridor and the Rhine-Danube corridor. The core of the TEN-T corridor network comprises 9 corridors, two of which are in the north-south direction, three are in the east-west direction, and there are four diagonal corridors. On the other hand, the routes of 10 pan-European transport corridors were formed aiming at inclusion, primarily in Central and Eastern Europe.

With its total length of $702 \mathrm{~km}$ (motorway component), Corridor Vc represents a link in the integration of the area between the Adriatic Sea and Central Europe, connecting Ploče, Mostar, Sarajevo, Zenica, Osijek, Udvar, Mohacs, Dunjauvaros, and Budapest. Starting at the Port of Ploče, the railway component connects the cities of Mostar, Sarajevo, Zenica, Osijek, Magyarbóly, Pecs, and Dambovar [4]. Apart from the $\mathrm{BiH}$ economy, the port hinterland includes the adjacent markets of Serbia, Hungary, eastern Austria, parts of the Czech Republic, Slovakia, Poland, and an area of western Romania to a certain extent, as well as the eastern Croatian area.

Numerous analyses have been carried out regarding the basic corridors linking Croatia with Europe, and relevant conclusions were derived about their importance for the port operations, as well as for the development and inclusion of Croatia in the European transport and market system $[4,5,6,7,8,9]$. The main objective of this study is to formulate concrete conclusions and offer recommendations for further 
development of the Port of Ploče. Structural and systemic research of current regional geo-political relations along the Corridor route was conducted, together with the Port's recent development programs regarding its development and geo-political function. The given recommendations are based on a vision of future solutions which presume close coordination with the $\mathrm{RH}$ government.

\section{FEATURES OF THE PORT OF PLOČE}

The Port of Ploče comprises two locations: Metković and Ploče, and has particular importance for $\mathrm{BiH}$ with natural gravitation spreading beyond. The Port owes its importance greatly to its geographic position and road links with other Adriatic ports and hinterland via the E-65 motorway, being the shortest connection between the Adriatic and Baltic Sea. The E-73 motorway has a direct link with Hungary. The port location provides excellent sea connections with South-Adriatic Italian ports [6].

The direct competitor of the Port of Ploče is the Port of Bar. Both ports primarily have the function of serving their immediate hinterland (eastern BiH, Serbia, and Montenegro), which at this point largely overlaps. The Port of Rijeka (Corridor Vb) acts as a second competitor, gravitating towards Budapest.

Table 1 - Features of other Croatian Adriatic ports

\subsection{Comparison of Port of Ploče with other Croatian Adriatic ports}

The most important features of the Adriatic Ports of Zadar, Šibenik, and Split are given in Table 1.

Although the Port of Zadar has modernly equipped infrastructure and superstructure, and it is integrated in the national transport system as well as in Corridor $\mathrm{V}$, there is no direct railway connection towards $\mathrm{BiH}$ and hinterland markets. This significantly reduces its transit importance to destinations outside the country, which is why it primarily relies on passenger traffic [7].

The Port of Šibenik is accessed through a channel 2,700 m long and $120 \mathrm{~m}$ to $300 \mathrm{~m}$ wide, preventing the navigation of vessels with capacities over 50,000 GT [12]. The Port of Šibenik is integrated in the road segment of the Pan-European Corridor $\mathrm{V}$ through $\mathrm{a}$ modern highway. A direct rail connection towards $\mathrm{BiH}$ is missing (the existing Unska railroad line is not in function).

The Port of Split is connected by road to Corridor $\mathrm{V}$, and it is integrated in the railway network in the Republic of Croatia; however, direct railway connection towards $\mathrm{BiH}$ is missing.

In 2016, the Port of Rijeka realized the biggest share of the total port turnover (Figure 1a). The shares of the Ports of Ploče and Split vary from 12.3 to $15.6 \%$. The Ports of Šibenik and Zadar have significantly lower

\begin{tabular}{|c|c|c|c|}
\hline & Port of Zadar & Port of Šibenik & Port of Split \\
\hline Feature & $\begin{array}{l}\text { special/international economic } \\
\text { interest }\end{array}$ & $\begin{array}{c}\text { special/international economic } \\
\text { interest }\end{array}$ & $\begin{array}{c}\text { special/international economic } \\
\text { interest }\end{array}$ \\
\hline $\begin{array}{l}\text { Terminals/ } \\
\text { capacity/ } \\
\text { draft }\end{array}$ & $\begin{array}{l}\text { 1. bulk terminal/500,000 t/12 m } \\
\text { 2. general cargo terminal / } \\
184,000 \mathrm{~m} 2 / 8.7 \mathrm{~m} \\
\text { 3. liquid cargo terminal/ } \\
75,000 \mathrm{~m} 3 / 10.3 \mathrm{~m} \\
\text { 4. terminal for a refrigerated food/ } \\
10,000 \mathrm{t} / 11.4 \mathrm{~m} \\
\text { 5. Ro-Ro terminal } \\
\text { 6. oil rig supply terminal } \\
\text { 7. passenger terminal }\end{array}$ & $\begin{array}{l}\text { 1. bulk terminal } / 120,000 \mathrm{t} / 10 \mathrm{~m} \\
\text { 2. timber terminal } / / 7 \mathrm{~m} \\
\text { 3. passengers terminal }\end{array}$ & $\begin{array}{l}\text { 1. container terminal/ } \\
30,000 \mathrm{TEU} / 10.4 \mathrm{~m} \\
\text { 2. truck terminal//7.5m } \\
\text { 3. Ro-Ro terminal//10.4 m } \\
\text { 4. passengers terminal }\end{array}$ \\
\hline $\begin{array}{l}\text { Prevailing } \\
\text { cargoes }\end{array}$ & $\begin{array}{l}\text { Oil \& liquid chemical, wheat, } \\
\text { soyabeans, corn, citrus fruits, sea } \\
\text { salt, timber, cement, palletized } \\
\text { and heavy cargoes }\end{array}$ & $\begin{array}{l}\text { Raw petrochemical materials } \\
\text { (phosphates, DAP - diammonium } \\
\text { phosphate, KCl - potassium } \\
\text { chloride, MAP - monoammonium } \\
\text { Phosphate), plastic pipes, } \\
\text { aluminium products, timber } \\
\text { products, sawn timber, general } \\
\text { cargo }\end{array}$ & $\begin{array}{l}\text { Metallurgical products, sugar, } \\
\text { salt, soyabeans, sulfur, citrus } \\
\text { fruits, special heavy cargoes, } \\
\text { containers }\end{array}$ \\
\hline $\begin{array}{l}\text { Direct railway } \\
\text { connection to } \\
\mathrm{BiH}\end{array}$ & No & No & No \\
\hline
\end{tabular}

Source: $[10,11,12,13,14]$ 


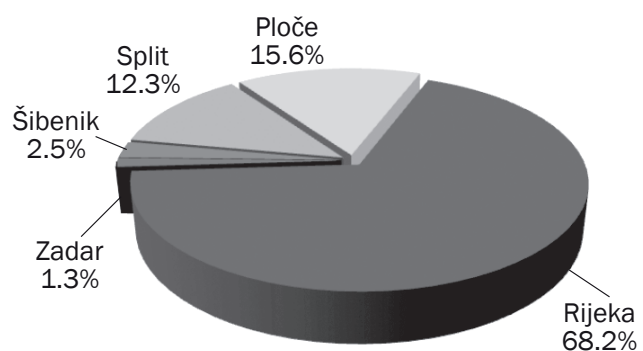

a)

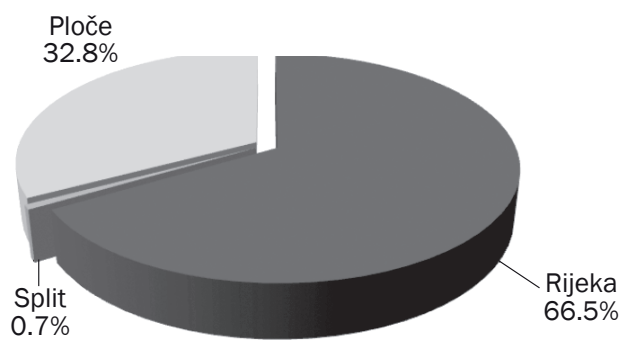

b)

Figure 1 - Share of total cargo turnover (2016) (left) and share of transit in total cargo turnover (2016) (right) of individual Croatian ports

Source: $[12,13,15]$

shares of cargo turnover. Analyses of the mentioned ports' capacities and organizational characteristics show that they are primarily focused on providing services to the local industry, with their turnover primarily achieved through export/import. Their transit turnover is of secondary importance [7], while the Port of Ploče primarily has this type of turnover (Figure $1 b$ ). The Ports of Zadar, Šibenik, and Split mainly base their existence on specialization of their services and development of passenger capacities. On the other hand, their lack of direct railway connections towards $\mathrm{BiH}$ restricts any significant access to the BiH market. The Ports of Split, Šibenik, and Zadar do not present major competition to the Port of Ploče.

\subsection{Traffic structure}

In Figure 2, statistical indicators of the turnover dynamics of the Port for the period from 2006 to 2016 are shown, with the share of most important groups of cargoes. Traffic growth began at the end of the War for Independence (1991-1995) with peak achievement of 5.08 million $t$ in 2008 . There was a significant drop of 2.25 million tons (a decrease by $44.3 \%$ ) in 2009 . The turnover increased to a total of 4.48 million tons in 2010, and then it kept decreasing until 2012 when it fell to 2.51 million tons, followed by a steady growth generating a total of 2.66 million tons in 2016.

Most of the turnover structure (70\% on average) is generated by bulk cargo, followed by liquids and containers. The total traffic reduction in 2009 is mostly a direct consequence of the loss of bulk cargo. Volume of coal turnover has the most significant share. A declining demand for coal and coke by $\mathrm{BiH}$ industry (with major customers such as the steel industry ArceIor Mittal, Mostar aluminium factory, coal mines, and power plant in Kakanj - TPP Ćatići) resulted in significant port turnover reduction [8]. However, resumption of production in 2010 stabilized the demand for coal, which resulted in its stable turnover. After 2011, a new

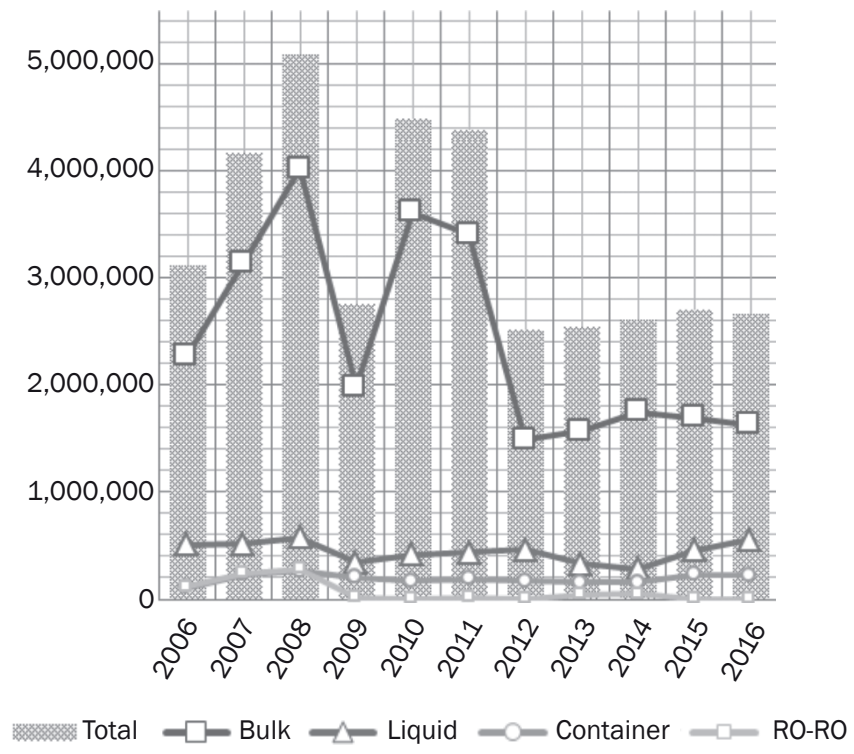

Figure 2 - Total traffic flow in the Port of Ploče for the period 2006-2016 with most important groups of cargo turnover (in tons)

Source: $[15,16,17,18,19,20,21]$ 

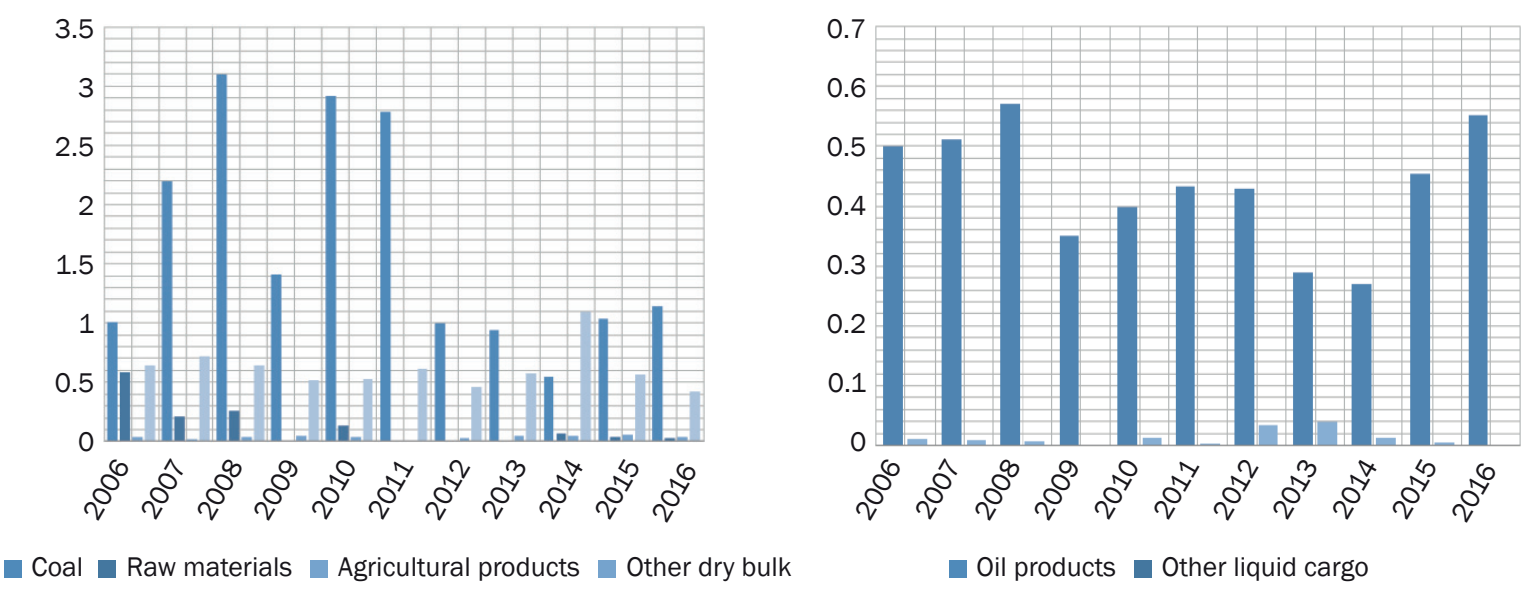

Figure 3 - The turnover of bulk (left) and most important liquid cargoes (right) in the Port of Ploče for the period 2006-2016 (in million tons)

Source: $[15,16,17,18,19,20,21]$

significant decline occurred due to the loss of coal demand for thermal power plants in southern Italy. Since then, the Port achieved a steady level of coal turnover. It is important to notice that coal transshipping for thermal power plants in Italy was carried out by bulk cargo vessels and did not depend on the Corridor Vc features. Thus the loss of this client emphasized the importance of Corridor $V_{c}$ for the Port. The peak of container traffic in 2008 amounted to 35,000 twenty-foot equivalent units (TEU), after which it continuously declined to 13,500 TEUs in 2014 , only to rise up to 23,000 in 2016 . The ratio of loaded and unloaded containers is particularly indicative (Figure 4).

The share of liquid cargoes in the total turnover of the Port of Ploče was $15.2 \%$ on average (in 2016, their share was $20 \%$, with petroleum products participation averaging 99.6\%) [21]. A decrease can be observed in the container traffic as well. Until 2011, their share was equal, and in some periods the number of loaded containers exceeded the number of unloaded containers. In the period 2012-2016, the share of loaded containers was $39.9 \%$ on average.

The Port of Ploče is primarily a transit port with the primary goal to supply markets in its immediate and neighboring hinterland. Since its foundation, the Port has focused on providing services mostly to the industry and the needs of $\mathrm{BiH}$, and it has been fully incorporated in the $\mathrm{BiH}$ traffic flow. After Croatia and $\mathrm{BiH}$ gained independence, the Port has made efforts to market its services to other gravitating areas, including presentations of port capacities and development plans to Bosnian companies which currently are

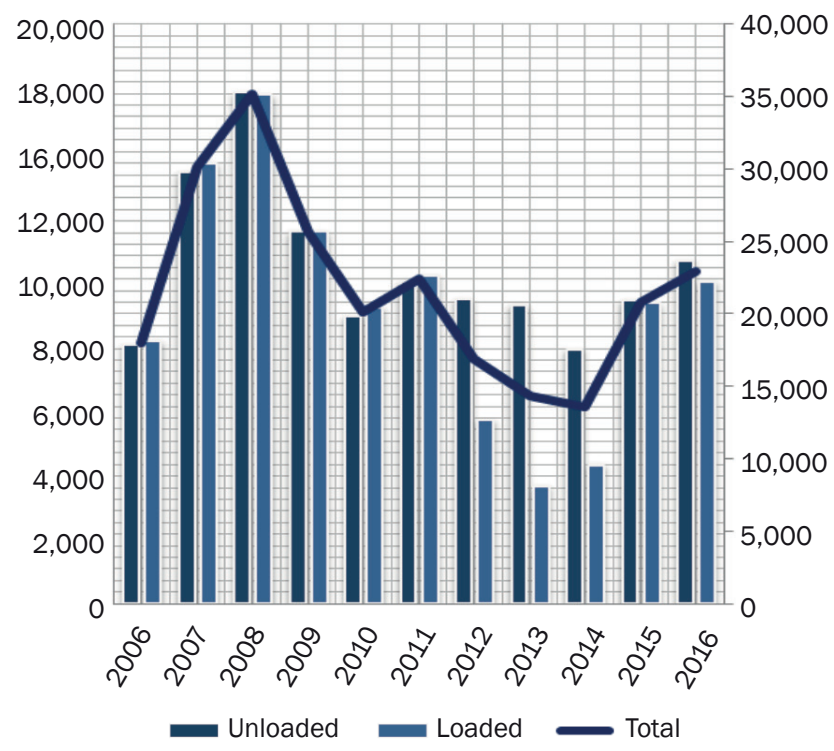

Figure 4 - Container traffic at the Port of Ploče for the period 2006-2016 (line - right y-axis), with the ratio of loaded and unloaded containers (in TEU) (bars - left y-axis) Source: $[15,16,17,18,19,20,21]$ 
not using the Port. However, the share of transit cargo for the BiH market in the Port's total turnover after the loss of clients in Italy averages 85\% [9]. Therefore, the $\mathrm{BiH}$ economic trends directly affect the Port's turnover.

The absence of expected, more significant growth of the $\mathrm{BiH}$ economy in the period after 2010 has decreased the container traffic. Moreover, there has also been a decrease in the number of loaded containers in the Port, indicating a slowdown in exports of the $\mathrm{BiH}$ economy, reaching its minimum in the period 2013-2014. The downward turnover trend began as a consequence of the global economic crisis, from which the $\mathrm{BiH}$ economy started to recover during 2014 and 2015 with a favorable growing trend of the share of loaded containers in container cargo traffic. (Figure 4).

\subsection{Investment cycle}

So far, the development of the Port of Ploče has been based on the needs of the $\mathrm{BiH}$ economy. However, in its efforts to reduce the share of traditional transportation services, increase the availability of additional logistics services, and to further exploit its natural position, the Port is participating in the project 'Trade and Transport Integration'(ITT) [22].

The project covers several investment projects:

1) Container terminal - during the first phase completed in 2010, a quay $280 \mathrm{~m}$ long and $27 \mathrm{~m}$ wide was built, with a Ro-Ro ramp and storage capacity of 60,000 TEU/year [22].

2) Bulk cargo terminal - its completion would increase the capacity of handling bulk cargo to more than 6 million tons per year. The terminal will be able to accommodate the vessels of up to 180,000 DWT and $19 \mathrm{~m}$ draft [22]. The necessary infrastructure was completed in mid-2016, and transshipment equipment installation and commencement of operation is expected during 2017.
3) Entry terminal - its construction is required in order to increase the competitiveness of the Port by speeding up and optimizing business processes of all stakeholders in the port operations.

4) The port information system, required to electronically connect all participants in the port procedures, thus enabling prompt, efficient, and reliable exchange of information.

In addition, the construction of a new terminal for liquid cargo was launched. The total capacity of the terminal $\left(242,000 \mathrm{~m}^{3}\right.$ of oil products and $31,000 \mathrm{~m}^{3}$ of liquefied petroleum gas) should be operational in the first quarter of 2018. The first phase of the terminal $\left(60,000 \mathrm{~m}^{3}\right.$ for petroleum products reception) was completed in September 2016, while the first phase of petroleum gas reception $\left(15,000 \mathrm{~m}^{3}\right)$ has been developing as planned and should be operational by mid2017. At this moment it is still under construction [23]. Analyzing the mentioned development of the ITT project programs, the following can be concluded:

- Investment decisions were made at a time when port operations generated continuous cargo growth, which certainly formed foundations for an extensive investment cycle,

- For the success of the projects, proper transport infrastructure is required, with the completion of the Corridor Vc as a primary task.

Although there is a discrepancy between the achieved port results and the assumptions based on the period of growth of port operations, it should be kept in mind that port facilities and development plans are normally considered for a period of minimum 20 to 30 years. Moreover, even under the present circumstances of reducing total cargo volumes and pending investment cycle, the Port regularly services its financial obligations while increasing operating income and revenue [24]. The new storage capacity, modernized entry terminal, and new information system would undoubtedly increase the competitiveness of the Port

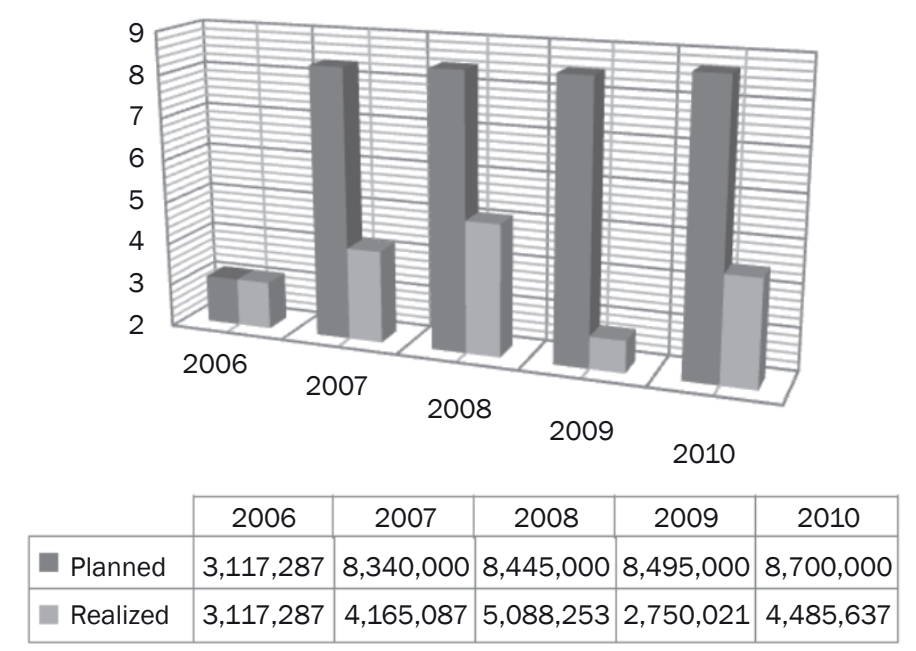

Figure 5 - Comparison of planned and realized turnover of the Port of Ploče in the period 2006-2010 (in mio tons) [9] 
and diversify its services. Additional confirmation for the current investment cycle can be found in the 'Draft Strategy of Export Growth' prepared by the BiH Export Council [25]. The document stipulates the necessary measures for the growth of $\mathrm{BiH}$ export and recommends measures that include:

- Improvement of efficiency and competitiveness of the BiH transport system,

- Creation and implementation of BiH transport integration strategy into the EU's intermodal strategy,

- Implementation improvement of the road and rail segments of the Corridor Vc,

- Implementation of the Law on Railways from 2005,

- Improvement of transport safety in $\mathrm{BiH}$.

The proposed measures foresee necessary steps toward a fully operational and functional $\mathrm{BiH}$ transport system, integrated in the EU transport systems, with the Corridor Vc as a vertical connection between Central Europe and the Adriatic Sea. The Port of Ploče represents the entry point of the Corridor Vc, and thus the current investment cycle has its business justification.

The completion of the ITT project would significantly increase the Port's capacity, efficiency, and quality of service. It could lead to competitive advantage, primarily regarding the Greek Port of Thessaloniki and the Montenegrin Port of Bar, whose gravitational fields overlap. Considering the North Adriatic ports, the Ports of Rijeka and Koper are the most significant competitors on the $\mathrm{BiH}$ market. Thus, the factors that the Port of Ploče should focus on and improve are the organization and efficiency of the port system, range of services, and quality and price of rendered services [6]. Outside of the Port's direct scope is the quality of transport connections with its gravitational area, directly related to the construction of the Corridor Vc.

Based on available data, the comparison of planned and actual results of the Port of Ploče indicates the need for additional caution in evaluation of development plans. At the same time, it points to a high degree of the Port's dependence on trends in the $\mathrm{BiH}$ economy. However, the biggest dilemmas are related to the Corridor Vc, whose full operational status acts as a key to the Port's successful operation.

\section{THE CONSTRUCTION DYNAMICS OF THE CORRIDOR Vc}

Full utility of the Corridor Vc would provide a modern motorway and railway connection of the Port with its own target markets, significantly increasing the possibility of attracting cargoes as well as that of overall expansion, since it would no longer be interesting only to $\mathrm{BiH}$ companies. On the other hand, following the completion of the Corridor, BiH would obtain a modern infrastructure connection with Central Europe and further, allowing the flow of goods and people, greater and faster integration into European markets, and thus internal economic and social consolidation. As for the Republic of Croatia, the Corridor Vc represents primarily the issue of transit and economic connections of the Port of Ploče and its positioning on the markets of Central and South-Eastern Europe. In addition, it will contribute to the revitalization and economic development of the north-eastern part of the country. Apart from its significance for transport and energy, the Corridor $V_{c}$ has an important socio-economic dimension for $\mathrm{BiH}$. The pan-European transport corridors were created, among other reasons, with the objective of integrating the European border territories into a common geo-political area. This is a special aspect in the magnitude of the Corridor Vc for Bosnia and Herzegovina.

\subsection{Past results of the Corridor Vc construction}

The Corridor Vc development level varies regarding the respective sections in Croatia and $\mathrm{BiH}$, both in terms of its road and rail components.

\subsubsection{Construction and condition of the Corridor Vc in Croatia}

The road component of the Corridor Vc in Croatia includes the following motorways:

- A5. The total length of the motorway is 86.5 kilometres, and it runs from Osijek, through Beli Manastir, up to the Hungarian border. Various sections of the motorway are in diverse stages of construction. The works are funded with the support of the EU, and it is expected that the whole section will be fully operational by 2020 .

- A1. The total length is $550 \mathrm{~km}$, running from Zagreb, through Split, along the $\mathrm{BiH}$ border to Dubrovnik. The section to Ploče has already been built.

- A10B. Ploče hub (A1). The entire motorway length of 8.9 kilometres has been built.

The railway components of the Corridor $V_{c}$ are shown in Table 2.

The motorway sections have been almost completely built and integrated into the international network of PE, meeting the requirements of modern traffic. The current state of the Corridor Vc railway component shows the unsatisfactory state of the railway infrastructure [27]. The signaling devices and existing rolling stock are obsolete, the maximum speed limit does not meet modern transit needs, and there are no contemporary multi-modal hubs. Compared to road transport, the stated drawbacks result in low traffic intensity and lack of competitiveness. The reconstruction and modernization of the Corridor railway are in progress, however, not in the planned volume (in 2013, 32.2 million HRK worth of investment were realized out of the planned 51.1 million) [20]. The upgrading and modernization of the railway line include: 
Table 2 - Railway components of the Corridor Vc in Croatia [26]

\begin{tabular}{||c|c|c|c|c|c||}
\hline Section & Route & $\begin{array}{c}\text { Distance } \\
{[\mathrm{km}]}\end{array}$ & Type of track* & $\begin{array}{c}\text { Max speed } \\
{[\mathrm{km} / \mathrm{h}]}\end{array}$ & Feature \\
\hline \hline M301.SB & $\begin{array}{c}\text { Hungarian border - Beli } \\
\text { Manastir - Osijek }\end{array}$ & 31.3 & Single track & 100 & Non-electrified \\
\hline M302 & Osijek - Strizivojna - Vrpolje & 48.3 & Single track & 100 & Non-electrified \\
\hline M303.A & $\begin{array}{c}\text { Strizivojna - Vrpolje - Sl. Šamac } \\
- \text { Sl. Brod (BiH border) }\end{array}$ & 24.1 & Single track & 100 & $\begin{array}{c}\text { Trains operate in } \\
\text { distance spacing blocks }\end{array}$ \\
\hline M304.SB & BiH border - Metković - Ploče & 21.9 & Single track & 80 & Trains operate in \\
distance spacing blocks
\end{tabular}

* Single/double track

- Construction of double track railway,

- Increase of speed to $160 \mathrm{~km} / \mathrm{h}$ and increase in axle load to $225 \mathrm{kN}$,

- Installation of the European Railway Train Management System (ERTMS) and centralized equipment for transport control,

- Installation/upgrade of telecommunications equipment, systems of electricity supply, drainage, and automatic level crossings systems, construction and modernization of stations and stops.

\subsubsection{Construction and condition of the Corridor Vc in $\mathrm{BiH}$}

The motorway section of the Corridor Vc passing through $\mathrm{BiH}$ is $336 \mathrm{~km}$ long, out of which $285 \mathrm{~km}$ go through the territory of the Federation of $\mathrm{BiH}$, and 51 $\mathrm{km}$ through the territory of Republika Srpska. The motorway route, divided into 4 sections, passes through geo-morphologically demanding terrains, requiring construction of tunnels $(70 \mathrm{~km})$ and bridges $(30 \mathrm{~km})$. So far, a total of $102 \mathrm{~km}$ have been built, with two sub-sections currently (2017) under construction.

There are major problems in the implementation of construction activities, since the funding of remaining sections is highly uncertain. So far, the construction has been financed by loans from the European Investment Bank and the European Bank for Reconstruction and Development, [28] with a small self-budgeted part. Currently, there is no clear plan for funding sources after 2019, which has led to delays in assessment of construction dynamics and the construction completion date. The most recent estimates by authorized $\mathrm{BiH}$ agencies speak of construction completion by the end of 2022 [29, 30].

\subsection{Analysis of the condition of the Corridor Vc railway section in $\mathrm{BiH}$}

In general, the worst situation is in the railway transport sector, as a result of the problems left from the pre-war period and the current $\mathrm{BiH}$ structure. Devastation of railway infrastructure occurred during the war, while in the post-war period conditions for a meaningful revitalization of the rail traffic were not created. The weak economic recovery has not generated significant demand for rail transport. The current capacity of the railway sector actually poses a restrictive factor to a more significant economic recovery of $\mathrm{BiH}$, since its present means cannot meet the growth of its economy, not even at the pre-war levels, which directly restricts the development plans of the Port of Ploče [31].

The biggest obstacles to a more efficient railway transport, particularly transit, are institutional, legal, and organizational bottlenecks [32]. Those are a consequence of BiH's internal structure. Trains crossing entity borders have to be stopped every time for replacement of locomotives, transport permits, and other documents, which increases costs and prolongs the transport time. If the shipment is sent to northeast Croatia or Hungary, it has to be stopped on the state border crossings for the required procedures and the replacement of the railway operator. The actual consignment transport time from the Port of Ploče to the consignee in $\mathrm{BiH}$ takes less than $20 \%$ of the total shipment time [32]. The rest of the time is spent on cargo handling and clearance procedure activities. This makes the average speed of consignment delivery 3-6 $\mathrm{km} / \mathrm{h}$ [33].

In the current conditions, an increase in the average speed of container rail shipments up to $10 \mathrm{~km} / \mathrm{h}$ can be achieved by reducing the cargo handling time in the Port of Ploče, thus reducing time breakdown for containerized cargo from 33 to 18.5 hours [32]. Organizational blockage would still remain.

The current BiH railway system structure poses a limiting factor to its development, since entity governments are in full control of the supervisory and management structure of railways. There is very limited cooperation at the state level, with neither common management strategy nor development. The restoration and reconstruction of existing Corridor lines takes place according to separate and inconsistent entity plans. The entities use different custom regulations and documentation forms, and the level of usage 
Table 3 - Indicators of the railway infrastructure condition of Corridor Vc in BiH in 2013 [33]

\begin{tabular}{|c|c|c|c|c|c|c|}
\hline Station & $\begin{array}{l}\text { Length } \\
{[\mathrm{km} / \mathrm{h}]}\end{array}$ & $\begin{array}{l}\text { Travel time } \\
{[\mathrm{min}]}\end{array}$ & Condition* & $\begin{array}{c}\text { Speed constraints } \\
{[\mathrm{km}]}\end{array}$ & $\begin{array}{l}\text { No. of } \\
\text { lines }\end{array}$ & $\begin{array}{l}\text { Infrastructure** } \\
\text { constraints }[\mathrm{km}]\end{array}$ \\
\hline Bosanski Šamac & \multirow{4}{*}{85} & \multirow{4}{*}{73} & \multirow{4}{*}{$\begin{array}{c}\text { poor/ } \\
\text { very poor }\end{array}$} & 16.5 & \multirow{4}{*}{1} & \multirow{4}{*}{85 significant } \\
\hline Modriča & & & & & & \\
\hline Koprivna Gornja & & & & 0.9 & & \\
\hline Osječani & & & & & & \\
\hline Doboj & \multirow{3}{*}{87} & \multirow{3}{*}{75} & \multirow{11}{*}{ medium } & & \multirow{3}{*}{2} & medium \\
\hline Maglaj & & & & 4.05 & & 4.05 significant \\
\hline Žepče & & & & & & \multirow{3}{*}{ medium } \\
\hline Jelina & 86 & 74 & & & \multirow{8}{*}{1} & \\
\hline Sarajevo & \multirow{7}{*}{170} & \multirow{7}{*}{146} & & & & \\
\hline Rastelica & & & & 3.1 & & 3.1 significant \\
\hline Bradina & & & & & & medium \\
\hline Raška Gora & & & & 4.17 & & significant \\
\hline Raštani & & & & & & medium \\
\hline Šumanci & & & & 0.89 & & significant \\
\hline Čapljina & & & & & & medium \\
\hline
\end{tabular}

* Very poor/poor/medium/good/very good; * *Significant/ medium constraints.

of IT technology in the data exchange is inadequate, although $\mathrm{BiH}$ participates in the program of Trade and Transport Facilitation in Southeast Europe (TTFSE). The legal framework for the reconstruction and management of the railway network from 2005 has not been implemented. The planned separation of railway network management between cargo and passenger transportation has not been conducted as well. All this makes the current railway system on the Corridor $V_{c}$ inefficient, expensive, and incapable of improving transport services and railway network [25].

With the current structure, railway companies are unsustainable without joint coordination, and their services are uncompetitive as compared to other transport modes. Within such environment, neither existing laws nor essential common legal framework are being implemented, preventing the reconstruction of the entire railway system. Currently, there are neither projects of railway infrastructure reconstruction nor sources for their funding [31].

In Table 3, indicators of the condition of the railway infrastructure of Corridor $\mathrm{Vc}$ in $\mathrm{BiH}$ (2013) are presented. The situation of the included railway lines is generally unsatisfactory. Within a total of $428 \mathrm{~km}, 20 \%$ is electrified with 2 tracks, while the maximum length of the train composition is $450-550 \mathrm{~m}$. Significant restrictions are imposed on $22.6 \%$ of the Corridor length, and moderate restrictions on $77.4 \%$.

\subsection{The perspective of the Corridor Vc railway component in $\mathrm{BiH}$ and geo-political issues}

Unlike the motorway components, the assessment of the Corridor Vc railway section includes substantially more unknowns. The main issue related to the motorway corridor is the completion date having been delayed several times, with 2022 being the target according to the latest official estimates. Although the completion depends on funding sources, all competent authorities and bodies in $\mathrm{BiH}$ agree on the feasibility of the motorway construction and completion. On the other hand, the problems that prevent a more intensive dynamics of the reconstruction and development of the railway corridor are much more complex, due to financial and geo-political reasons.

In forming the approach to the railway component of the Corridor, different views and interests of the two $\mathrm{BiH}$ entities are evident. The main dilemmas of the Corridor specified in analyses relating to the Republika Srpska areas are as follows [34]:

- Important industrial centers and transport hubs (Banja Luka, Prijedor, Bihać, Bijeljina, Tuzla, Zvornik, Trebinje etc.) remain excluded from the direct impact of the Corridor.

- The planned corridor route would not create the conditions for the territorial cohesion of the two most important centers in $\mathrm{BiH}$, the cities of Banja Luka and Sarajevo.

- The Corridor does not lead to a more intensive regional cooperation, i.e., the current RS authorities focus their efforts on the motorway connection to the Corridor $X$, in order to form the route Zagreb-Okučani-Gradiška-Banja Luka-Šipovo-Split. Further, their geo-political and macro-economic interests are related to the use of the Sava River Basin and its ports on the Corridor VII. In terms of their regional interests, the Port of Ploče is of secondary importance [34]. 
Unresolved issues affecting the development of the Corridor railway component in the Federation of Bosnia and Herzegovina stem from unsettled issues between $\mathrm{BiH}$ and the Republic of Croatia, which hinders efforts to establish $\mathrm{BiH}$ as an important maritime country [35]. Their views arise from the basic starting points:

- $\mathrm{FBiH}$ is trying to establish $\mathrm{BiH}$ as a maritime country which will represent the entry point in the Central-European markets. Having this in mind, the Port of Neum has become a part of spatial plans. Considering that, the request of the $\mathrm{BiH}$ authorities for the height of the upcoming Pelješac bridge to be at least $55 \mathrm{~m}$ is understandable. Combined with the existing water depth of $24 \mathrm{~m}$, as well as the favorable spatial layout of the future port, it would enable the development and sustainability of the Port of Neum.

- The Croatian Parliament has never ratified the text of the Agreement of Croatia and Bosnia and Herzegovina on the Port of Ploče and Neum from 1998. That agreement was intended for the joint management of the Port of Ploče and the establishment of two independent transport corridors: first through Neum to connect the territory of the Republic of Croatia, and second through the Port of Ploče for the needs of $\mathrm{BiH}$. The independent corridor through the Port of Ploče would allow $\mathrm{BiH}$ an uninterrupted traffic of all kinds of goods to third countries without any restrictions, and without any or with minimum costs.

Observing the above-mentioned assumptions, BiH's reluctance is evident regarding the contribution of the Corridor to its geo-political plans. Although the Corridor would include $\mathrm{BiH}$ in the European transport system, the impact on internal linking and integration in the Central European geo-political space would be absent. Instead of the process of interregional and international cooperation, the current state of $\mathrm{BiH}$ is characterized by internal struggles and confrontation with neighboring countries, certainly being a consequence of dysfunctional internal organization and the post-war heritage [34]. In such circumstances, though for different reasons, the $\mathrm{BiH}$ entities do not support the construction completion and reconstruction of the railway Corridor Vc, thereby making its full realization extremely uncertain at the moment.

\section{POTENTIAL APPROACHES AND DEVELOPMENT ALTERNATIVES OF THE PORT OF PLOČE}

This chapter offers guidelines and potential possibilities of development of the Port of Ploče considering two main, interconnected segments: the construction dynamics of the Corridor Vc and the geo-political issues of the region.

\subsection{Construction dynamics of the Corridor Vc in the function of port development}

The Corridor's railway component is the most important factor in successful implementation of the Port's development plans, reflected by several indicators:

- The Port of Ploče is not connected with the railway system of the Republic of Croatia but rather with the $\mathrm{BiH}$ railway system.

- Based on available data, the share of Port's railway traffic ranges from $60.92 \%$ to $91.69 \%$ (Figure 6). This high rate is the result of the $\mathrm{BiH}$ economy's high orientation towards the Port, which was an integral part of the former state until 1990.

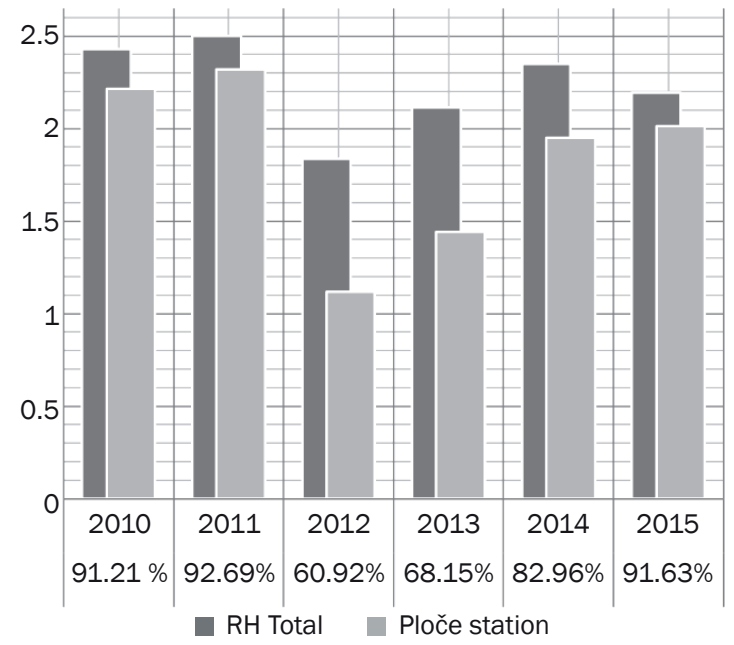

Figure 6 - Share in the traffic (in mio tons) of railway station Ploče within the overall railway traffic of the Republic of Croatia $(\mathrm{RH})$ regarding $\mathrm{BiH}$ destinations Source: $[16,17,18,19,20,21]$ 
- Current investment and ITT project plans for the Port will result in a significant container capacity increase and extension of liquid and bulk cargo terminals. Although railway transport participates in the shipping of containers from Croatian ports with about 25\% [36], for a more successful performance on the markets of Central Europe, it is necessary to increase the share of railway transport of containers (either by introducing a block trains composition or individual freight lines).

The planned attraction of larger container traffic seems more uncertain. It is affected by the fact that in the total container traffic of the Port of Ploče the $\mathrm{BiH}$ market participates with $88.35 \%$, Croatian with $9.58 \%$, and other markets with $2.07 \%$ [6]. Therefore, the planned container traffic increase can only be realized with new markets. The primary prerequisite for that would be the realization of the railway Corridor Vc. The same conclusion can be made for the planned increase of bulk cargo traffic. In the case of bulk cargo return to the Italian market, the share of land transport would be reduced. However, since the primary markets of the Port of Ploče are in its hinterland, the share of land transport will continue to be extremely high. The planned increase of liquid cargo storage, as well as the construction of gas terminals, will also require a further increase of the railway transport share, since the route of the Corridor $\mathrm{Vc}_{\mathrm{c}}$ through $\mathrm{BiH}$, unlike other European corridors, does not follow the construction of gas and other pipelines, energy or communication systems.

\subsection{Alternatives to ensure future development of the Port of Ploče considering geo- political issues}

The lack of modernization and Corridor Vc development within $\mathrm{BiH}$ and its uncertain economic and geopolitical situation brings into question the justification of further ERTMS and railway system investment in the Croatian part. The development of the TEN-T railway network is strongly linked with EU transport and economic policy planning and realization. The structure and quantity of expected cargoes are essential factors in making the investment decision. It is doubtful whether the Corridor's economic and geo-political environment can generate the necessary traffic growth of the Port of Ploče, thus attracting private investors and providing a return on investment into corridor modernization within an acceptable timeframe. The EU irrevocably co-finances up to $50 \%$ of total costs for projects having a significant integration role (projects covering at least three member states, three transportation modes, and two transboundary sections) $[37,38]$. In this way, otherwise privately unattractive infrastructural traffic facilities can be realized. Here, the unpreparedness of the $\mathrm{RH}$ authorities comes to the fore as well. For the period 2007-2013, the share of non-refundable grants (within the Cohesion Fund) in the construction and modernization of the railway system was as high as $85 \%$ [39]. RH has not taken this advantage for the necessary construction (adequate capacities) and modernization (adequate train velocities) of the railway Corridor Vb connecting the Port of Rijeka and Budapest, whose realization was foreseen for the period 2008-2012. Co-financing of the road component in the TEN-T program framework is possible with a transboundary-featured project. This would be applicable to the completion of the construction of the part of the Corridor to Hungarian border and the section Sredanci - BiH border.

Investments in railway infrastructure must be based on agreed studies of realistic estimates of the quantities of cargo and relations of the socio-economic costs and benefits. The EU criteria additionaly include contributions to European investment value, spatial integration, regional economics' accessibility, and the contribution to social development of participating countries. For the decision on the investment of $\mathrm{RH}$ into the $\mathrm{Vc}$ railway infrastructure, two standpoints have to be considered:

1) The gravitating hinterland of the Port of Ploče is undeniably medium to large $(\mathrm{BiH}$ and surrounding area).

2) The railway link enables increasing the competitiveness of the Port of Ploče on a significant level.

These are two fundamental prerequisites for increasing the turnover of the Port of Ploče. Considering the current geo-political and economic conditions of the areas gravitating to the Port of Ploče, the EU criteria may be crucial in decision-making towards the modernization and construction of the Corridor $V_{c}$ railway component in Croatia. Although $\mathrm{BiH}$ is not an EU member state, and therefore no funds are available for TEN-T project development, it can participate in the frame of the SEETO organization and use the European Bank for Reconstruction and Development (EBRD) and World Bank (WB) funds for TEN-T development on its territory.

Considering the Port's surroundings, its current development, business operations, investment plans, and orientations, and by analyzing the available sources relevant to the status and construction of the Corridor $\mathrm{Vc}$, as well as geo-political relations in a wider context, several approaches would reduce business uncertainty and increase the comparative advantages of the Port:

1) Intensify contacts with existing clients in $\mathrm{BiH}$ and offer them additional benefits while approaching economic entities in $\mathrm{BiH}$ that do not currently use the port services. This is primarily related to the territory of Republika Srpska. Several presentations 
have already been given before Bosnian companies at the BiH Foreign Trade Chamber.

2) Form a standpoint together with the Government of the Republic of Croatia, and, in cooperation with the $\mathrm{BiH}$ authorities, find a solution acceptable to both sides, and in accordance with the 1998 Agreement of the Republic of Croatia and Bosnia and Herzegovina on the Port of Ploče and Neum. The emphasis should be placed on the part relating to the management of the Port with the right of free access to the Port. Although the problem is much more complex because it involves unresolved maritime delimitation with $\mathrm{BiH}$ and the issue of connecting two parts of Croatia, it would be necessary to enable a more meaningful participation of $\mathrm{BiH}$ in the operation of the Port. The Croatian EU membership should not be an obstacle to taking such initiatives.

3) Simultaneously, new activities should be introduced in the port area: endeavor the development of the hub service, to attract logistics and distribution centres of foreign companies, and to encourage industrial function of the port. Efforts are being made in this direction to establish the Port as a logistical hub for exploration of hydrocarbons in the Adriatic.

Observing the current and planned investment cycles, the environment, and the Port's importance, it is obvious that the implementation of development plans is not possible without the participation of Croatian authorities. Due to the geo-political importance of the Corridor, solutions should be searched in the economic and geo-political domains. Considering the complexity of the problem, it would be wrong to establish an approach based on two standpoints.

The first standpoint is reliance on current relations with $\mathrm{BiH}$, assuming that its market 'naturally' gravitates towards the Port of Ploče. The 'natural' orientation comes from the fact that the Port was an integral part of BiH's industrial and transport system, over which it has lost influence after 1990, and which has certainly burdened mutual relations. The second argument - the geographic focus - is increasingly losing its importance in the formation of modern transit flows, while potential clients give priority to comparative advantages of other ports. As an example, the Serbian market meets its own needs for container transport [9] through the Port of Rijeka (60\%) and the Ports of Bar and Thessaloniki (40\%), even though Port of Ploče is geographically much more affordable.

The second standpoint is ignoring the plans for the Port of Neum. Considering the current economic relations in $\mathrm{BiH}$ and the scale of investment required to start the new port project, it is certain that $\mathrm{BiH}$ is not able to undertake such a project on its own. However, it should be remembered that in $1997 \mathrm{BiH}$ authorities launched an initiative for the implementation of the Port of Neum with Turkish partners [35]. Although the project was not implemented due to the unfavorable internal political situation in Turkey at that time, the initiatives still exist. The likelihood of realization will depend in the first place on regulation of the relations with Croatia, including border separation, joint corridor issues, as well as on BiH's right to unimpeded access to the sea and reaching a mutually acceptable agreement.

\section{CONCLUSION}

The vital importance of the Corridor $V_{c}$ for profiling the Port of Ploče as a modern multimodal hub was confirmed by the analysis of the structure of the cargo. Types of cargo and dominant commodities were analyzed for the period 2006-2016 along with their dynamics and destinations during the study period. The analyses confirmed $\mathrm{BiH}$ as the dominant market for the Port, as well as the area where the Corridor Vc attains the most significant transport and geo-political impact. Separate analyses were provided for the Corridor's road and rail components, and for the current level of development and perspectives related to the continuation of construction. The section through $\mathrm{BiH}$ is the key to the success of the entire Corridor project, especially the railway component. Different internal approaches for further development of the Corridor can be observed by analyzing the level of completeness of the Corridor and its prospects in $\mathrm{BiH}$, both from infrastructural and socio-economic standpoints.

Assessment of development plans and valorization of investment are out of the direct scope of this paper. Considering all undertaken efforts and development projects of the Port, it is easy to observe the uncertainty of anticipated traffic growth achievement of the Port under the existing socio-economic complexity of $\mathrm{BiH}$. Focusing on the impact of the Corridor $\mathrm{Vc}_{\mathrm{c}}$ on the activity of Port of Ploče, specific approaches were given. These approaches could significantly increase the chances for adequate completion of the Corridor. They would secure the necessary conditions for the Port to step on other potential markets. Apart from an affirmative approach to the current situation, the paper also deals with the potentially harmful attitudes that should not be ignored while approaching the $\mathrm{BiH}$ side.

It is necessary to point out that the Port of Ploče is not able to define a strategy of cooperation with the Bosnian side on its own, but that representatives of Croatian authorities should actively participate in the process as well. The causes of the most significant issues related to the $\mathrm{BiH}$ section of the Corridor $\mathrm{Vc}$ have their origin both in the internal geo-political relationships and in unresolved relations with the Republic of Croatia. 
A completed and operational Corridor Vc, primarily its railway component, is the main prerequisite for development. In that regard, closer cooperation is required from all interested parties, as well as from all economic and political participants.

SERĐO KOS, Ph.D. ${ }^{1}$

E-mail: skos@pfri.hr

MARIO BAKOTA, mag.ing.naut. ${ }^{2}$

E-mail: mbakota@pfst.hr

DAVID BRČIĆ, Ph.D. ${ }^{1}$

E-mail: brcic@pfri.hr

${ }^{1}$ Sveučilište u Rijeci, Pomorski fakultet

Studentska 2, 51000 Rijeka, Hrvatska

2 Sveučilište u Splitu, Pomorski fakultet

Ruđera Boškovića 37, 21000 Split, Hrvatska

\section{ANALIZA UTJECAJA TRANSPORTNOG KORIDORA VC NA LUKU PLOČE}

\section{SAŽETAK}

Dosadašnji značaj luke Ploče ogleda se prvenstveno u opsluživanju bosanskohercegovačkog tržišta. Međutim paneuropski koridor Vc omogućava pristup znatno širem tržištu centralne i jugoistočne Europe. Svrha ovog rada je da se formiraju stavovi o budućem razvoju koridora Vc, te sukladno tome i preporuke s posljedicama na luku Ploče, pri čemu je korištena metodologija uključuje analizu, komparaciju i sintezu podataka robnih tokova luke Ploče te podataka o dinamici izgradnje koridora Vc. Obuhvaćeni su odnosi BiH s Republikom Hrvatskom, te se procjenjuje značenje koridora Vc za svaku zemlje. Statistički pokazatelji ukazuju na neophodnost dovršetka koridora Vc za uspješnu realizaciju razvojnih planova luke Ploče. Analiza stanja koridora upućuje na trenutno prevladavajuće okolnosti unutar BiH koji čine njegovu realizaciju u krajnjoj mjeri neizvjesnom, što naročito vrijedi za željeznički segment koridora. Rezultati ukazuju da najvažnije prepreke za uspješnu realizaciju razvojnih planova luke Ploče nisu samo unutarnji geo-politički odnosi unutar BiH, već i sporna pitanja BiH i RH. Posljedično, pokazano je da luke Ploče ne može sama definirati i provesti potrebne mjere u odnosu na BiH, već uz nužno sudjelovanje vlade $R H$. Analiza rezultira stavovima i preporukama koje bi unaprijedile odnose s BiH čime bi se u znatnoj mjeri potakao završetak izgradnje koridora Vc unutar BiH, što bi omogućilo luci Ploče punu afirmaciju na ciljanim tržištima.

\section{KLUČNE RIJEČI}

luka Ploče; tokovi tereta; izgradnja koridora Vc; teritorijalna cjelovitost $\mathrm{BiH}$;

\section{REFERENCES}

[1] European Commision. European Commission Infrastructure - TEN-T - Connecting Europe. 2012; Available from: http://ec.europa.eu/transport/themes/infrastructure/ten-t-guidelines/corridors/index_en.htm [Accessed 15 $5^{\text {th }}$ Nov 2016].

[2] European Commission. TEN-T - projects in Figures. 2013; Available from: https://ec.europa. eu/inea/sites/inea/files/download/publications/ tenea_numbers_201306_final.pdf $\quad$ Accessed $18^{\text {th }}$ Dec 2017].

[3] European Commision. European Commission Trans-European Networks for Energy 2017; Available from: https://ec.europa.eu/energy/en/topics/infrastructure/trans-european-networks-energy. [Accessed $5^{\text {th }}$ Jan 2018]

[4] Dundović Č, Kesić B, Kolanović I. Značenje i uloga izgradnje prometnih koridora u razvitku luke Ploče. Pomorski zbornik. 2006;43(1): 113-130. Croatian

[5] Poletan Jugovic T. The integration of the Republic of Croatia into the Paneuropean Transport Corridor Network. Pomorstvo. 2006;20(1): 49-65.

[6] Rathman D, Kružić B, Poletan Jugović T. Analysis of the competitiveness of Port of Ploče at the container transport market and the possibilities for improvement. Pomorstvo. 2015;29: 40-44.

[7] Zelenika R, Mrvčić A, Pavlić Skender H. Analysis and assessment of efficiency degree in operation of cargo seaports in the Republic of Croatia. Naše more. 2011;58(1-2): 9-21.

[8] Poletan Jugović T, Jolić N, Kavran Z. Comparative Analysys of Cargo Flows on Branches Vb and Vc of the Pan-European Corridor Vc. Promet - Traffic \& Transportation. 2009;21(3): 205-216.

[9] Poletan Jugović T. Analiza relevantnih indikatora formiranja robnih tokova na paneuropskom koridoru Vc. Pomorstvo, 2008;22(2): 185-208. Croatian

[10] Luka Šibenik 2017. Available from: http://lukasibenik. $\mathrm{hr} /$ [Accessed 18 ${ }^{\text {th }}$ Mar 2017].

[11] tris.com.hr 2014. Pojačan pretovar u luci Šibenik ali $i$ prašenje mineralnih gnojiva. [cited $21^{\text {st }}$ Dec 2016] Available from: http://tris.com.hr/2014/ 06/pojacan-pretovar-u-luci-sibenik-ali-i-prasenjemineralnih-gnojiva.

[12] Port Authority Šibenik. Available from: http://www. portauthority-sibenik.hr/hrv/luka_sibenik/index.asp [Accessed 21 ${ }^{\text {st }}$ Feb 2017]

[13] Port of Zadar. Available from: http://www.luka-zadar.hr [Accessed $21^{\text {st }}$ Feb 2017]

[14] Port Authority Split. Available from: http://portsplit. com/ [Accessed 21 ${ }^{\text {st }}$ Feb 2017]

[15] Državni zavod za statistiku RH. Statistička izvješća transport i komunikacije 2016. Zagreb; 2017. Croatian

[16] Državni zavod za statistiku RH. Statistička izvješća transport i komunikacije 2014. Zagreb; 2015. Croatian

[17] Državni zavod za statistiku RH. Statistička izvješća transport i komunikacije 2011. Zagreb; 2012. Croatian

[18] Državni zavod za statistiku RH. Promet u morskim lukama od 2006. do 2010. Zagreb; 2011. Croatian

[19] Državni zavod za statistiku RH. Statistička izvješća transport i komunikacije 2012. Zagreb; 2013. Croatian

[20] Državni zavod za statistiku RH. Statistička izvješća transport i komunikacije 2013. Zagreb; 2014. Croatian

[21] Državni zavod za statistiku RH. Statistička izvješća transport i komunikacije 2015. Zagreb; 2016. Croatian

[22] Port Authority Ploče. [cited $16^{\text {th }}$ Nov 2016] Available from: http://www.ppa.hr/index.php/2015-04-17-0854-45/kontejnerski-terminal.html

[23] poslovni.hr 2016. Za dvije godine uvozit ćemo UNP morskim putem. [cited 19 ${ }^{\text {th }}$ Dec 2016] Available from: 
http://www.poslovni.hr/poduzetnik/za-dvije-godineuvozit-cemo-unp-morskim-putem-309449

[24] Luka Ploče d.d. Godišnje izvješće i konsolidirani i nekonsolidirani financijski izvještaji za Društvo luka Ploče za 2016. godinu. Croatian. Ploče: Luka Ploče d.d; 2017. [cited 18 ${ }^{\text {th }}$ Mar 2017] Available from: http://www.luka-ploce.hr/repository/files/0/f/Ofd60820afObf3ac5c43ccfffac0c83d.pdf

[25] $\mathrm{BiH}$. Nacrt Strategije rasta izvoza BiH od 2012. do 2015. godine. 2011; p. 113-114. Croatian. Izvozno vijeće BiH; 2011.[cited 23 ${ }^{\text {rd }}$ Nov 2016] Available from: http://komorabih.ba/wp-content/uploads/2013/06/ bhepa-nacrt-strategija-rasta-izvoza-bih.pdf

[26] vlakovi.hr. Koridori u Hrvatskoj. Available from: http:// www.vlakovi.hr/?page_id=2701 [Accessed $16^{\text {th }}$ Aug 2016 ].

[27] Hrvatska. Modernizacija-zeljeznica. Zagreb: Ministry of Maritime Affairs, Transport and Infrastructure Available from: http://www.promet-eufondovi.hr/modernizacija-zeljeznica [Accessed $9^{\text {th }}$ Nov 2016 ].

[28] oslobodjenje.ba 2018. Pocetak-novog-ciklusa-investiranja-u-bih-70-miliona-za-5c. [cited $12^{\text {th }}$ Jan 2018] Available from: https://www.oslobodjenje.ba/vijesti/ bih/pocetak-novog-ciklusa-investiranja-u-bih-70-miliona-za-5c

[29] večernji.ba 2016. Do-2020-izgradit-cemo-dvije-trecine-autoceste-na-koridoru-5c. [cited $18^{\text {th }}$ Mar 2017] Available from: https://www.vecernji.ba/vijesti/ do-2020-izgradit-cemo-dvije-trecine-autoceste-na-koridoru-5c-1063833

[30] večernji.ba 2015. Realno-je-da-koridor-vc-bude-izgraden-do-2022-godine. [cited 18 ${ }^{\text {th }}$ Mar 2017] Available from: https://www.vecernji.ba/vijesti/realno-je-dakoridor-vc-bude-izgraden-do-2022-godine-1030396

[31] European Commission. Support to Bosnia and Herzegovina in implementation of the commitments in Transport Sector under the Stabilisation and Association Agreement; 3-4, 21- 22, Available from: http://ec.europa.eu/enlargement/pdf/bosnia_and_ herzegovina/ipa/2012/7pf_transportbih2012.pdf [Accessed 20 th Dec 2016].

[32] Čulo K, Skenderović V. The Challenge of Removing Freight traffic Bottlenecks on the Corridor Vc. Presentation The world bank. University of Osijek; 2005.

[33] South East Europe Transport Observatory (SEETO) 2013. Summary of Infrastructure Limitations; 2013. Available from: http://www.seetoint.org/wp-content/ uploads/downloads/2014/11/1_Corridor_Vc.pdf [Accessed $4^{\text {th }}$ Nov 2016].

[34] Marić D. Corridor Vc as a Factor of Integration of Bosnia and Herzegovina into the European Union. Faculty of Sceince, University of Banja Luka; 2012. p. 94, 96100. doi:10.2298/IJGI1201089M

[35] vijesti.ba 2012. BiH bi izgradnjom luke Neum prestala biti ovisna od luke Ploče. [cited $16^{\text {th }}$ Sep 2016] Available from: http://vijesti.ba/clanak/98287/bihbi-izgradnjom-luke-neum-prestala-biti-ovisna-od-lukeploce

[36] Kos S, Brčić D, Karmelić J. Strukturna analiza kontejnerizacije hrvatskih luka. Pomorstvo. 2010;24(2): 189-209. Croatian

[37] European Court of Auditors. Special report no 08/2016: Rail freight transport in the EU: still not on the right track, 2016. Available from: https://www. eca.europa.eu/en/Pages/Docltem.aspx?did=36398 [Accessed 15 ${ }^{\text {th }}$ Dec 2017].

[38] Amanović S, Kralj S. Optimizacija željezničkog povezivanja Rijeke i Trsta, Željeznice 21, 2016;15(2): 7-15. Croatian

[39] Ministarstvo Mora Prometa i Infrastrukture. Nacionalni program željezničke infrastrukture za razdoblje od 2016. do 2020. godine; 2015. Available from: http://www.mppi.hr/UserDocsImages/Nacionalni\%20 program\%2OHZI\%2024-9_15.pdf [Accessed 14 ${ }^{\text {th }}$ Jan 2018]. 